\title{
Comparative Genomic Analysis of Pseudomonas chlororaphis PCL1606 Reveals New Insight into Antifungal Compounds Involved in Biocontrol
}

\author{
Claudia E. Calderón, ${ }^{1}$ Cayo Ramos, ${ }^{2}$ Antonio de Vicente, ${ }^{1}$ and Francisco M. Cazorla ${ }^{1}$ \\ ${ }^{1}$ Departamento de Microbiología and ${ }^{2}$ Área de Genética, Instituto de Hortofruticultura Subtropical y Mediterránea "La \\ Mayora", Universidad de Málaga, Consejo Superior de Investigaciones Científicas, IHSM-UMA-CSIC, Facultad de Ciencias, \\ Campus de Teatinos s/n, 29071 Málaga, España
}

Submitted 16 October 2014. Accepted 4 December 2014.

\begin{abstract}
Pseudomonas chlororaphis PCL1606 is a rhizobacterium that has biocontrol activity against many soilborne phytopathogenic fungi. The whole genome sequence of this strain was obtained using the Illumina Hiseq 2000 sequencing platform and was assembled using SOAP denovo software. The resulting 6.66-Mb complete sequence of the PCL1606 genome was further analyzed. A comparative genomic analysis using 10 plant-associated strains within the fluorescent Pseudomonas group, including the complete genome of $P$. chlororaphis PCL1606, revealed a diverse spectrum of traits involved in multitrophic interactions with plants and microbes as well as biological control. Phylogenetic analysis of these strains using eight housekeeping genes clearly placed strain PCL1606 into the $P$. chlororaphis group. The genome sequence of $P$. chlororaphis PCL1606 revealed the presence of sequences that were homologous to biosynthetic genes for the antifungal compounds 2-hexyl, 5-propyl resorcinol (HPR), hydrogen cyanide, and pyrrolnitrin; this is the first report of pyrrolnitrin encoding genes in this $P$. chlororaphis strain. Single-, double-, and triple-insertional mutants in the biosynthetic genes of each antifungal compound were used to test their roles in the production of these antifungal compounds and in antagonism and biocontrol of two fungal pathogens. The results confirmed the function of HPR in the antagonistic phenotype and in the biocontrol activity of $P$. chlororaphis PCL1606.
\end{abstract}

Pseudomonas is a large genus within the $\gamma$ subclass of Proteobacteria known for its ubiquity in the environment, utilization of a striking variety of organic compounds as energy sources (Lessie and Phibbs 1984; Wu et al. 2010), and production of an array of secondary metabolites (Bender et al. 1999; Gross and Loper 2009; Raaijmakers et al. 2002). Certain strains live

Whole-genome DNA sequence of Pseudomonas chlororaphis PCL1606 is deposited in the GenBank database under accession Bioproject ID PRJNA263136.

Corresponding author: F. M. Cazorla; Telephone: +34 952137587; Fax: +34 952136645; E-mail: cazorla@uma.es

* The $\boldsymbol{e}$-Xtra logo stands for "electronic extra" and indicates that five supplementary figures and two supplementary tables are published online.

(C) 2015 The American Phytopathological Society in a commensal relationship with plants, protecting them from infection by pathogens that would otherwise cause disease (Haas and Defago 2005; Lugtenberg and Kamilova 2009; Weller 1988). For example, rhizospheric Pseudomonas spp. can function as key components of ecological processes that suppress plant soil disease in agricultural and natural environments (Mazzola 2004; Mendes et al. 2011; Weller et al. 2002).

Due to the spectrum of ecological, metabolic, and biochemical characteristics of the genus Pseudomonas, it is not surprising that diversity among Pseudomonas spp. extends to the genomic sequence level. As additional genomic information becomes available, developments in genomic technologies can provide further insight into essential life processes (Collins et al. 2003). Comparative genomics has emerged as a powerful tool to identify functionally important genomic elements (Rodriguez-Palenzuela et al. 2010; Silby et al. 2009; Wu et al. 2010). A comparison of genomes within the Pseudomonas fluorescens group provided ample evidence that the tremendous ecological and physiological diversity of these bacteria extends to the genomic level (Loper et al. 2012).

The complete genomes of several species from the fluorescent group of Pseudomonas have now been sequenced (Baltrus et al. 2011; Loper et al. 2012; Paulsen et al. 2005; RedondoNieto et al. 2012; Shen et al. 2013; Silby et al. 2009, 2011) and only 25 to $35 \%$ of the genome of each strain is composed of core genes shared by all members of the genus (Loper et al. 2012). The genomes of Pseudomonas spp., like those of many other bacteria, display a highly mosaic structure, being composed of relatively stable core regions interspersed with regions that vary among the strains (Kimbrel et al. 2010; Paulsen et al. 2005; Silby et al. 2009, 2011). Regions that are unique to a specific strain are thought to shape that strain's distinctive characteristics, including its interactions with plant pathogens that are targets of biological control. Many of the unique genomic regions have features of horizontally acquired DNA (i.e., transposons, prophages, or genomic islands). Therefore, these features may be exploited as markers of genomic regions that define the distinctive attributes of an individual strain. Consequently, novel compounds, including antimicrobials, have been discovered using genomic-guided approaches (Loper et al. 2012).

Many biological control rhizobacterial strains have certain characteristics in common: the capacity to colonize plant surfaces, specifically the infection site of target pathogens; and the production of antibiotics toxic to target pathogens or the 
induction of systemic resistance responses in the plant (Haas and Defago 2005; Haas and Keel 2003). Antibiotics, which function as major determinants of biological control, fall into diverse classes, including the phenazines (Mavrodi et al. 2006; Pierson and Pierson 2010), polyketides (Gross and Loper 2009; Weller et al. 2007), cyclic lipopeptide (CLP) biosurfactants (Raaijmakers et al. 2010), and many others. Some strains of Pseudomonas spp. also produce phytohormones (Kang et al. 2006; Loper and Schroth 1986; Spaepen et al. 2007) or metabolites that alter plant hormone levels (Leveau and Gerards 2008; Xiao and Xu 2007), which directly influence the growth and development of their plant associates (Arshad and Frankenberger 1998). Other strains induce resistance responses in plants against disease (Bakker et al. 2007; Han et al. 2006). Plant-commensal strains of Pseudomonas spp. are intricately enmeshed in plant and soil biology through all of these diverse activities, and their functions as biological control agents have distinguished them as microorganisms with significant effects on agricultural productivity.

P. chlororaphis PCL1606 was isolated from the roots of healthy avocado trees in an area affected by the soilborne pathogenic Rosellinia necatrix, causing avocado white root rot (Pliego et al. 2012). This strain has broad antagonistic activity (Cazorla et al. 2006) and suppresses the phytopathogenic activity of Rosellinia necatrix and Fusarium oxysporum f. sp. radicis-lycopersici. Previous experiments have demonstrated that $P$. chlororaphis PCL1606 produces the antifungal antibiotic 2-hexyl, 5-propyl resorcinol (HPR) and the antifungal volatile compound hydrogen cyanide (HCN) (Cazorla et al. 2006). Recently, HPR has been reported to be crucial for biological control and root colonization by $P$. chlororaphis PCL1606 (Calderón et al. 2013, 2014a). Here, we provide a comparative analysis of the genomic sequence of $P$. chlororaphis PCL1606 with nine other genomes from previously sequenced plant-associated Pseudomonas spp. strains isolated from various habitats, including soil and plant root and leaf surfaces, which exhibit biological control activities against bacterial, fungal, and oomycete pathogens through varied mechanisms (Table 1). Some of the strains used for the comparative analysis were obtained from disease-suppressive soils that exhibit natural processes of biological control due to the presence of indigenous microbiota that are antagonistic to soilborne plant-pathogenic fungi or nematodes. Genomes of many
P. chlororaphis associated with herbaceous plants have been previously sequenced (Loper et al. 2012) but, as far as we know, this is the first report of the genome sequencing of a biocontrol $P$. chlororaphis strain isolated from the roots of a woody tree. Additionally, in those previously sequenced $P$. chlororaphis strains, the presence of genes encoding for production of antifungal compounds has been confirmed (phenazines, pyrrolnitrin, cyanhydric acid, and 2-hexyl, 5-propilresorcinol); however, P. chlororaphis PCL1606 does not show those genes associated with phenazine production, which are considered not essential for biocontrol of Sclerotinia sclerotiorum (Selin et al. 2010) but crucial for biocontrol of F. oxysporum (Chin-A-Woeng et al. 1998). Thus, elucidation of the role of the different antifungal compounds in biocontrol must be deciphered. For this, we complemented our genomic analysis with a phenotypic characterization of the antifungal antibiotics produced by $P$. chlororaphis PCL1606 to determine the role of these different compounds in the biocontrol ability of this strain.

\section{RESULTS AND DISCUSSION}

\section{General genome features.}

The genome features for each of the 10 plant-associated Pseudomonas spp. strains analyzed are summarized in Table 2. The comparative analysis of these Pseudomonas spp. strains was performed using the online tools from the CLgenomics program. The characteristics (size, GC content, number of protein-coding genes, and number of rRNA, tRNA, and other RNA genes) are within the range of previously sequenced Pseudomonas spp. genomes (Silby et al. 2011). The 10 selected genomes had a wide range of genome sizes, ranging from 5.59 to $7.07 \mathrm{M}$, with the number of protein-coding genes ranging from 5,597 to 6,223 , indicating substantial strain-tostrain variation (Table 2). The assembled genome of $P$. chlororaphis PCL1606 had approximately 180-fold coverage, and this sequence is $6,662,896 \mathrm{bp}$ in length, arranged in two contigs $(6,646,309$ and $16,587 \mathrm{bp})$, which is assembled as a single circular chromosome for analysis (Fig. 1; Supplementary Fig. S1). Among the studied Pseudomonas strains, P. chlororaphis PCL1606 has the highest value for $\mathrm{G}+\mathrm{C}$ content $(64.01 \%)$, followed by $P$. protegens Pf-5 (63.30\%), and then the remaining P. chlororaphis strains (62.93 to 63.15\%) (Table 2).

Table 1. Pseudomonas strains used in this study

\begin{tabular}{|c|c|c|c|}
\hline Strain & Source & Target diseases for biological control & Genome reference \\
\hline \multicolumn{4}{|c|}{ Pseudomonas chlororaphis } \\
\hline PCL1606 & Avocado rhizosphere, Spain & $\begin{array}{l}\text { Avocado white root rot, tomato foot, and } \\
\text { crown rot }\end{array}$ & This study \\
\hline GP72 & Rhizosphere of green pepper, China & Phytopathogens suppression & Shen et al. 2012 \\
\hline O6 & Soil, Utah, U.S.A. & Wildfire of tobacco, spot of cucumber & Loper et al. 2012 \\
\hline \multicolumn{4}{|c|}{ P. chlororaphis subsp. aureofaciens } \\
\hline $30-84$ & $\begin{array}{l}\text { Wheat rhizosphere, Washington, } \\
\text { U.S.A. }\end{array}$ & Take-all of wheat & Loper et al. 2012 \\
\hline \multicolumn{4}{|c|}{ P. protegens } \\
\hline Pf-5 & Soil, Texas, U.S.A. & Seedling emergence & Paulsen et al. 2005 \\
\hline \multicolumn{4}{|c|}{ P. brassicacearum } \\
\hline Q8r1-96 & $\begin{array}{l}\text { Wheat rhizosphere, Washington, } \\
\text { U.S.A. }\end{array}$ & Take-all of wheat & Loper et al. 2012 \\
\hline \multicolumn{4}{|c|}{ P. fluorescens } \\
\hline PfO-1 & Soil, Massachusetts, U.S.A. & Not detailed $^{\mathrm{a}}$ & Silby et al. 2009 \\
\hline Q2-87 & $\begin{array}{l}\text { Wheat rhizosphere, Washington, } \\
\text { U.S.A. }\end{array}$ & Take-all of wheat & Loper et al. 2012 \\
\hline SBW25 & $\begin{array}{l}\text { Sugar beet phyllosphere, Oxfordshire, } \\
\text { U.K. }\end{array}$ & Seedling emergence & Silby et al. 2009 \\
\hline F113 & Sugar beet rhizosphere & $\begin{array}{l}\text { Pythium ultimun, Phytophthora cactorum, } \\
\text { and Fusarium oxysporum }\end{array}$ & Redondo-Nieto et al. 2012 \\
\hline
\end{tabular}

${ }^{a}$ Potentially important for biocontrol (Silby and Levy 2004). 
In general, the genome features of $P$. chlororaphis strains PCL1606, O6, and 30-84 are very similar. The average genome size of Pseudomonas spp. isolated from the plant rhizosphere is lower (average of $6.63 \mathrm{Mbp}$ ) than those isolated from soil (average of $6.83 \mathrm{Mbp}$ ) and from phyllosphere (only one representative strain of $7.15 \mathrm{Mbp})$. P. chlororaphis GP72 has a lower number of RNA genes when compared with the other $P$. chlororaphis (Table 2).

Table 2. General genomes features of the 10 studied Pseudomonas spp.

\begin{tabular}{lcccccrrrrr}
\hline Features & PCL1606 & GP72 & O6 & $\mathbf{3 0 - 8 4}$ & Pf-5 & Pf0-1 & Q8r1-96 & Q2-87 & SBW25 & F113 \\
\hline Chromosome size (Mbp) & 6.66 & 6.66 & 6.98 & 6.67 & 7.07 & 6.44 & 6.60 & 6.37 & 6.77 & 6.85 \\
G+C content (\%) & 64.01 & 63.13 & 62.93 & 62.95 & 63.3 & 60.52 & 60.96 & 60.63 & 60.50 & 60.78 \\
RNA genes & 157 & 80 & 143 & 160 & 115 & 119 & 279 & 241 & 97 \\
rRNA genes & 16 & 4 & 7 & 19 & 16 & 19 & 16 & 19 & 16 & 16 \\
tRNA genes & 71 & 56 & 60 & 74 & 71 & 73 & 65 & 68 & 66 & 66 \\
Other RNA genes & 70 & 20 & 72 & 67 & 28 & 27 & 198 & 154 & 15 & 8 \\
Protein-coding genes & 6,107 & 6,005 & 6,223 & 5,848 & 6,108 & 5,722 & 5,715 & 5,597 & 5,921 & 5,862 \\
Contigs & 2 & 347 & 30 & 13 & 1 & 1 & 5 & 2 & 1 \\
\hline
\end{tabular}

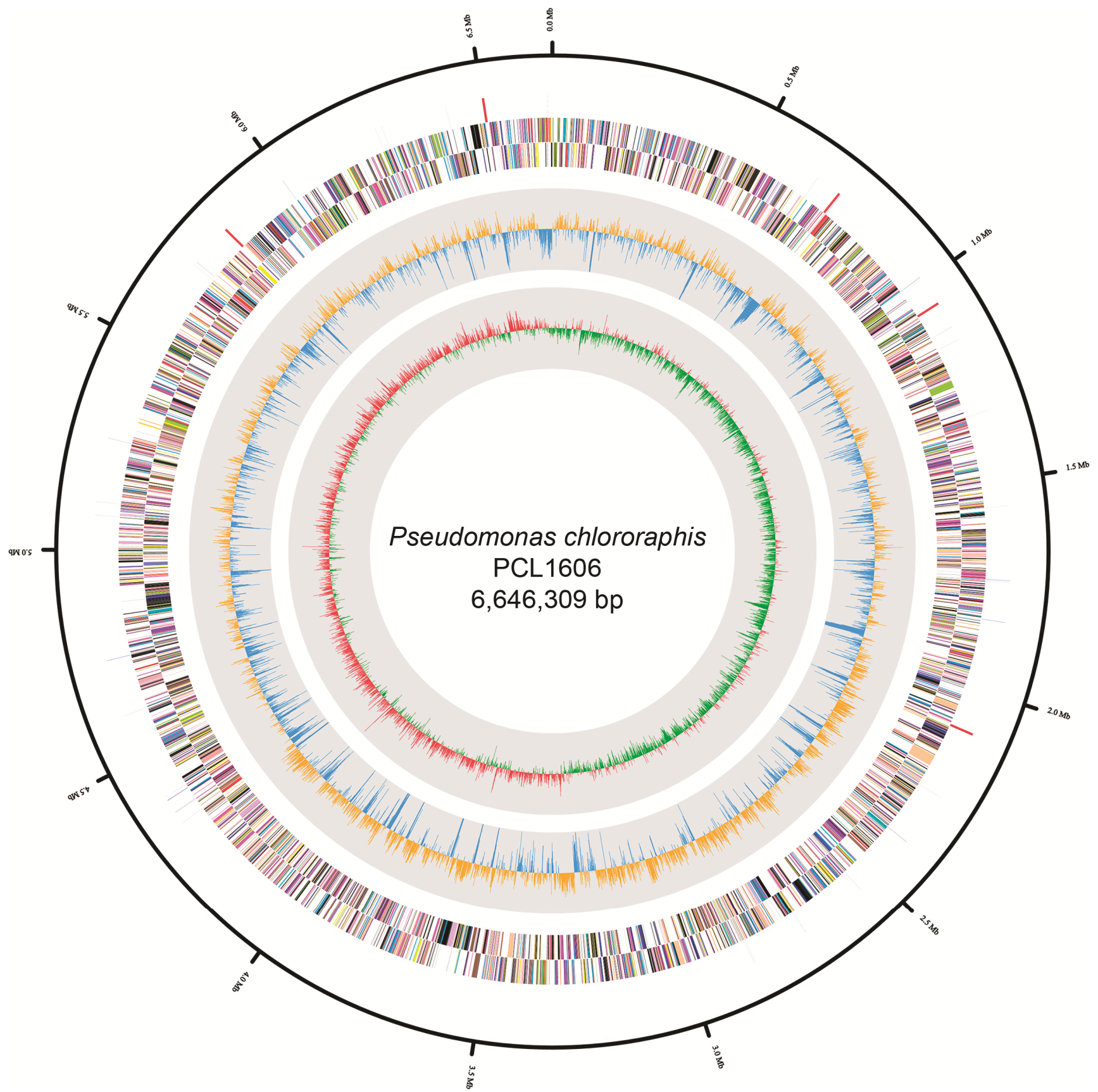

Fig. 1. Circularized genome map of Pseudomonas chlororaphis PCL1606. The 6.65-Mbp contig was merged at the $3^{\prime}$ end with the $5^{\prime}$ end of the $16.6-\mathrm{Kbp}$ contig, generating circularized sequence. The first nucleotide of the map corresponds to the first nucleotide of the 6.65-Mbp contig. Each ring of the circle has a different genome information: rRNA/tRNA, reverse coding sequence (CDS), forward CDS, GC skew, and GC ration from the outermost ring moving in. Each color corresponds to a different cluster of orthologous group functional annotation. 
Phylogenetic analysis.

The phylogenetic relationship of P. chlororaphis PCL1606 with the other Pseudomonas spp. strains was further analyzed by comparing a set of eight protein-coding housekeeping genes (rpoB, rpoD, gyrB, recA, ascA, aroE, mutL, and guaA) (Fig. 2). The resulting phylogenetic tree showed that the 10 selected Pseudomonas strains grouped into a single large clade composed of three subclades. The four strains of $P$. chlororaphis were allocated into subclade 1 . In this subclade, $P$. chlororaphis PCL1606 grouped together with the other sequenced $P$. chlororaphis strains, which is in agreement with previous results (Calderón et al. 2013). The biocontrol strain $P$. protegens Pf-5 (Table 1) is distantly associated with this group. Our analysis is also consistent with a recent report that assigned strain Pf-5 to the new species $P$. protegens, which is related to $P$. chlororaphis but also has distinct differential properties (Ramette et al. 2011).

Subclade 2 is composed of three $P$. fluorescens strains (Table 1 ) and the P. brassicacearum Q8r1-96 strain (previously classified as $P$. fluorescens). In this subclade, $P$. fluorescens Pf0- 1 is also distantly associated with the remaining strains inside this cluster. This fact has been previously reported for this strain and the $P$. protegens Pf-5 strains, supporting the hypothesis that these strains reside in distinct lineages that will become more defined as the genomes of sister strains become available in the future (Loper et al. 2012). Subclade 3 included $P$. fluorescens biocontrol strain SBW25 along with other different Pseudomonas strains.
All of the strains in subclades 1 and 2 were isolated from plant roots or soil (Table 1). In subclade 3, strain SBW25, isolated from the leaves of sugar beet in England (Table 1), appears along with other two $P$. fluorescens strains: A506, which was isolated from leaf surfaces (Wilson and Lindow 1993), and SS101 isolated from wheat roots (Mazzola et al. 2007). Subclade 3 also includes the previously sequenced strain $P$. synxantha BG33R, which was isolated from the root of a peach tree (Kluepfel et al. 1993). These results are consistent with the results previously described in other studies (Loper et al. 2012), and these phylogenies are also congruent with those from a recent report in which a large number of strains representing many species of Pseudomonas were evaluated (Mulet et al. 2010). In this study, $P$. fluorescens and $P$. chlororaphis strains were also allocated in different clades from the other Pseudomonas spp.

\section{Comparison among $\boldsymbol{P}$. chlororaphis genomes.}

In total, $6,107,6,223,5,848$, and 6,005 protein-coding genes (including hypothetical proteins) of the $P$. chlororaphis strains PCL1606, O6, 30-84, and GP72, respectively, were reported. The analysis of the $P$. chlororaphis genomes identified 4,598 predicted protein-coding genes in a core genome for this group (Fig. 3). P. chlororaphis PCL1606 had the highest number of specific genes (19.4\% of the genes, 1,186 genes) (Fig. 3; Supplementary Table $\mathrm{S} 2$ ), which included genes related to the type IV secretory pathway, fimbria genes, and the pyochelin gene cluster. The other Pseudomonas strains present a smaller num-

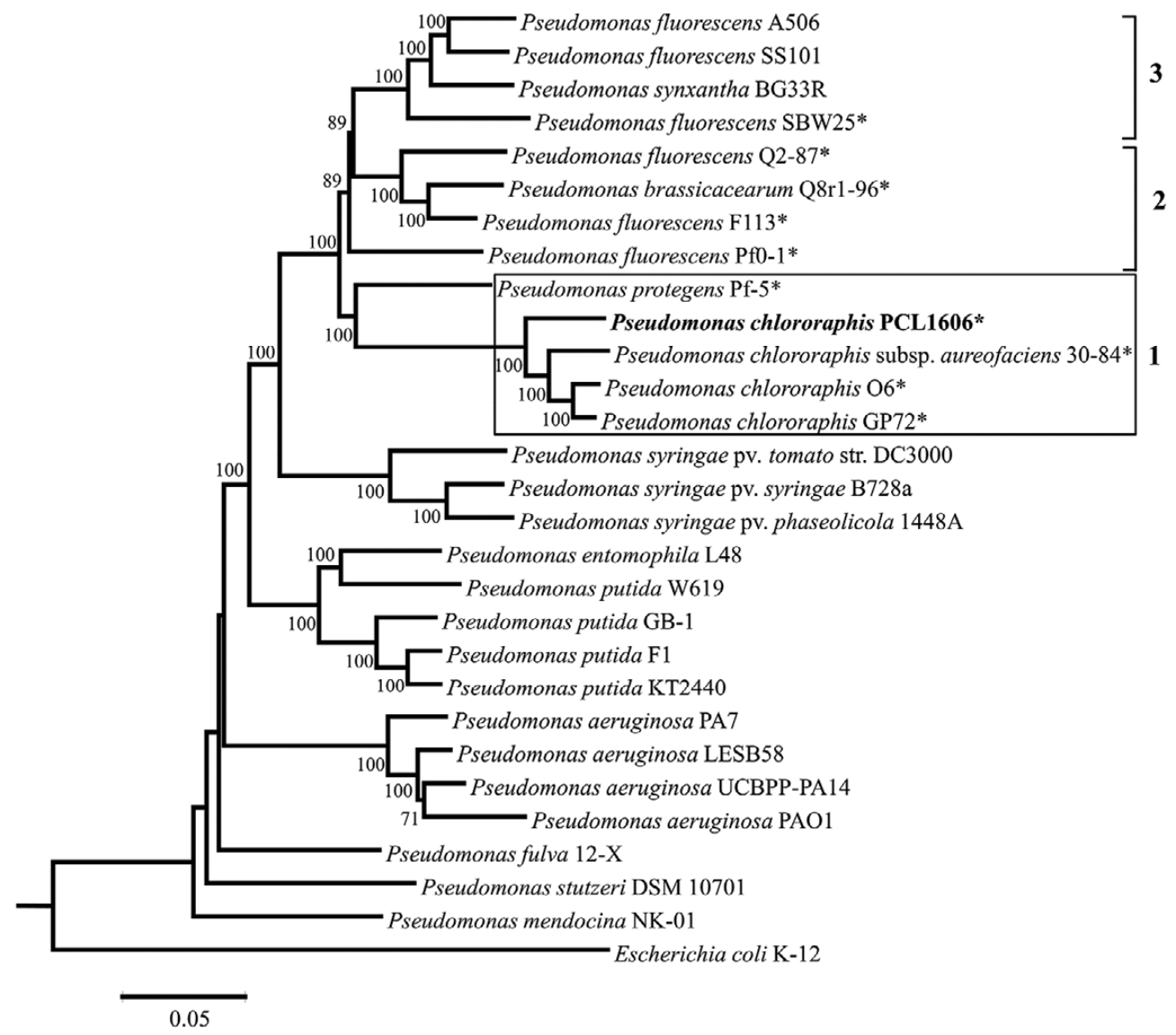

Fig. 2. Phylogenetic tree showing the relationship of the sequenced Pseudomonas spp. strains. The tree is based on the concatenated alignments of eight core housekeeping genes-rpoB, rpoD, gyrB, recA, acsA, aroE, mutL, and guaA (approximately $15 \mathrm{Mb}$ ) - and was generated using MEGA 5 (Tamura et al. 2011). Escherichia coli K-12 was used as an outgroup. The bar indicates sequence divergence. Percent bootstrap values of more than $70 \%$ (from 1,000 replicates) are indicated at the nodes. Strains of the Pseudomonas fluorescens group congregated within a single clade consisted of three subclades (lines showed), which are numbered 3 to 1 . The P. chlororaphis groups analyzed in this study and P. protegens Pf-5 are in a box. P. chlororaphis PCL1606, sequenced in this study, is marked in bold. 
ber of specific genes: 408, 418, and 328 protein-coding genes for O6, 30-84, and CP72 strains, respectively.

A comparison of the functional categories based on clusters of orthologous groups was performed with the four P. chlororaphis genomes (Table 3 ). These results confirmed those obtained from the Venn diagram, where the $P$. chlororaphis strains are very similar, with a number of genes involved in different functions.

\section{Analysis of genes encoding \\ for antifungal related compounds.}

Antimicrobial compounds toxic to phytopathogenic fungi, oomycetes, and bacteria are important contributors to biological control, including secondary metabolites, such as antimicrobial antibiotics, lipopeptides, siderophores, and toxins (Raaijmakers et al. 2002). Due to our interest in antifungal compounds, the presence of genes for well-known antifungal compounds was identified in the genome sequences of each selected strain (Table 4).

The analysis of the selected genomes revealed that the $P$. chlororaphis group displayed the consistent presence of HPR, pyrrolnitrin (PRN), HCN, and phenazine (PHZ). However, $P$. chlororaphis PCL1606 does not have PHZ genes in its genome. Along with these strains, Pf-5 is another strain from subclade 1 that harbors genes for the biosynthesis of antimicrobial antibiotics, such as 2,4-diacetylphloroglucinol (DAPG), PRN, HCN, and pyoluteorin genes (Paulsen et al. 2005) and rhizoxin genes (Gross and Loper 2009). The other biocontrol strains displayed genes for only one antimicrobial compound, such as Pf0-1 that has an HCN gene; or two compounds, such as the strains Q8r1-96, Q2-87, SBW25, and F113 that harbor genes for DAPG and HCN production. The cluster for $\mathrm{HCN}$ production is observed in the genome for all the strains, except in P. fluorescens SBW25. However, $P$. fluorescens SBW25 did not have any antifungal antibiotic genes in its genome. The gene cluster for prodigiosine and oocydin A were not present in this Pseudomonas strain.

CLP are a class of compounds produced by many strains of Pseudomonas spp. that exhibit surfactant, antimicrobial, antipredation, and cytotoxic properties (Gross et al. 2007; Mazzola et al. 2009; Raaijmakers et al. 2006, 2010). No genes coding for CLP have been detected in either P. chlororaphis PCL1606 or any other sequenced $P$. chlororaphis strain. Genes coding for production of the CLP orfamide A are present in the Pf-5

Table 3. Comparative analysis of the functional categories bases on COG of the protein-coding genes of the P. chlororaphis strains analyzed ${ }^{\mathrm{a}}$

\begin{tabular}{|c|c|c|c|c|}
\hline Functional categories based on COG (\%) & PCL1606 & GP72 & 06 & $30-84$ \\
\hline Translation, ribosomal structure and biogenesis & $242(3.96)$ & $243(4.05)$ & $245(3.94)$ & $240(4.10)$ \\
\hline Transcription & $589(9.64)$ & $559(9.31)$ & $577(9.27)$ & $546(9.34)$ \\
\hline Replication, recombination and repair & $170(2.78)$ & $169(2.81)$ & $201(3.23)$ & $168(2.87)$ \\
\hline Cell cycle control, cell division, chromosome partitioning & $51(0.83)$ & $53(0.88)$ & $53(0.85)$ & $56(0.96)$ \\
\hline Posttranslational modification, protein turnover, chaperones & $227(3.72)$ & $236(3.93)$ & $236(3.79)$ & $224(3.83)$ \\
\hline Cell wall/membrane/envelope biogenesis & $349(5.72)$ & $363(6.04)$ & $395(6.34)$ & $355(6.07)$ \\
\hline Cell motility & $217(3.55)$ & $186(3.10)$ & $192(3.09)$ & $187(3.20)$ \\
\hline Inorganic ion transport and metabolism & $385(6.30)$ & $362(6.03)$ & $362(5.82)$ & $349(5.97)$ \\
\hline Signal transduction mechanisms & $321(5.26)$ & $312(5.20)$ & $338(5.43)$ & $318(5.44)$ \\
\hline Energy production and conversion & $371(6.07)$ & $374(6.23)$ & $377(6.06)$ & $365(6.24)$ \\
\hline Carbohydrate transport and metabolism & $325(5.32)$ & $341(5.68)$ & $333(5.35)$ & $316(5.40)$ \\
\hline Amino acid transport and metabolism & $653(10.69)$ & $652(10.86)$ & $650(10.44)$ & $620(10.60)$ \\
\hline Nucleotide transport and metabolism & $134(2.19)$ & $131(2.18)$ & $140(2.24)$ & $133(2.27)$ \\
\hline Coenzyme transport and metabolism & $228(3.73)$ & $247(4.11)$ & $244(3.92)$ & $226(3.86)$ \\
\hline Lipid transport and metabolism & $307(5.03)$ & $302(5.03)$ & $309(4.97)$ & $284(4.86)$ \\
\hline Secondary metabolites biosynthesis, transport and catabolism & $123(2.01)$ & $130(2.16)$ & $130(2.08)$ & $120(2.05)$ \\
\hline General function prediction only & $743(12.17)$ & $706(11.76)$ & $743(11.94)$ & $694(11.87)$ \\
\hline Function unknown & $672(11.00)$ & $639(10.64)$ & $698(11.22)$ & $647(11.06)$ \\
\hline
\end{tabular}

${ }^{a}$ These results were generated using CLGenomics software. Number of genes and percentage (in parentheses) are shown. In each column, total $=100 \%$.

Table 4. Detection of genes of compound present in the analyzed sequences of selected Pseudomonas spp.

\begin{tabular}{|c|c|c|c|c|c|c|c|c|c|c|c|c|c|c|}
\hline \multirow[b]{2}{*}{ Strain } & \multicolumn{7}{|c|}{ Antimicrobial antibiotic volatiles ${ }^{a}$} & \multicolumn{2}{|c|}{$\begin{array}{c}\text { Cyclic- } \\
\text { lipopeptides }\end{array}$} & \multicolumn{4}{|c|}{ Siderophores } & \multirow[b]{2}{*}{$\begin{array}{c}\text { Toxins } \\
\text { 猔 }\end{array}$} \\
\hline & 采 & $\stackrel{t}{a}$ & Z & Z & $\stackrel{N}{2}$ & 5 & 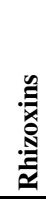 & 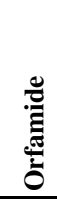 & 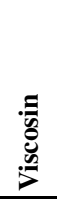 & 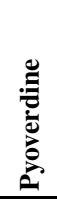 & 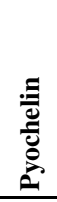 & 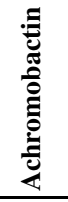 & 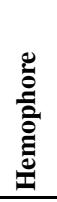 & \\
\hline \multicolumn{15}{|l|}{ Subclade 1} \\
\hline PCL1606 & + & - & + & + & - & - & - & - & - & + & + & + & - & + \\
\hline GP72 & + & - & + & + & + & - & - & - & - & + & - & + & - & + \\
\hline 06 & + & - & + & + & + & - & - & - & - & + & - & + & - & + \\
\hline $30-84$ & + & _- & + & + & + & _- & - & - & - & + & - & + & - & + \\
\hline Pf-5 & - & + & + & + & - & + & + & + & - & + & + & - & + & + \\
\hline \multicolumn{15}{|l|}{ Subclade 2} \\
\hline Pf0-1 & - & - & - & + & - & - & - & - & - & + & - & - & - & - \\
\hline Q8r1-96 & - & + & - & + & - & - & - & - & - & + & - & - & - & - \\
\hline Q2-87 & - & + & - & + & - & - & _- & - & - & + & - & - & - & - \\
\hline F113 & - & + & - & + & - & - & - & - & + & + & - & - & + & - \\
\hline \multicolumn{15}{|l|}{ Subclade 3} \\
\hline SBW25 & - & - & - & - & - & - & - & - & + & + & - & - & + & - \\
\hline
\end{tabular}

${ }^{\mathrm{a}} \mathrm{HPR}=$ 2-hexyl, 5-propyl resorcinol, DAPG = 2,4-diacetylphloroglucinol, PRN = pyrrolnitrin, HCN $=$ hydrogen cyanide, PHZ = phenazine, and PLT = pyoluteorin. 
genome, in which orfamide A has been demonstrated to have a role in bacterial motility and to exhibit antimicrobial activity (Gross et al. 2007). Genes coding for production of the CLP viscosin were localized in the genome of $P$. fluorescens SBW25 (de Bruijn et al. 2007) and P. fluorescens F113. The gene clusters for arthrofactin, massetolide, putisolvin, amphisin, and entolysin were not present in any of the Pseudomonas strains analyzed.

The fluorescent pseudomonads are characterized by their production of fluorescent pigments in the large and diverse pyoverdine class (Visca et al. 2007), which function as siderophores for iron acquisition by the bacterial cell. Many genes are involved in the biosynthesis, utilization, and regulation of the pyoverdine iron-acquisition system (Cornelis et al. 2009), and all these Pseudomonas spp. have a full complement of pyoverdine genes, which can be present in three to seven clusters dispersed throughout the genome (Loper et al. 2012), improving the biocontrol ability of the Pseudomonas strains (Meyer 2000). Many Pseudomonas spp. produce secondary siderophores that also contribute to iron nutrition (Cornelis et al. 2009), such as pyochelin, which is only produced in the $P$. protegens Pf-5 (Youard et al. 2007) and P. chlororaphis PCL1606 strains. The gene clusters for the biosynthesis and transport of the siderophore achromobactin (Berti and Thomas 2009) are present in all P. chlororaphis strains (Table 4), suggesting specificity to this group, but the functional production of these secondary siderophores has not been confirmed.

In addition, the three genomes of Pf-5, SBW25, and F113 had a full set of the genes required for the biosynthesis and efflux of hemophore (Table 4), a protein that, when exported from the cell, can chelate heme with high affinity and then be bound and taken up by specific outer-membrane receptors (Wandersman and Delepelaire 2004).

Finally, certain strains in the $P$. fluorescens group can be toxic to insects and, in some cases, this toxicity is associated with the gene clusters encoding the Mcf (makes caterpillars floppy) toxin produced by the entomopathogen Photorhabdus luminescens (Daborn et al. 2002). Another gene, fitD (fluorescens insect toxin), which is closely related to $m c f$, is present in the genome of Pseudomonas protegens Pf-5 and is associated with that strain's lethality against the tobacco hornworm Manduca sexta (Pechy-Tarr et al. 2008). The fitABCDEFGH locus is located in the genome of Pf-5 and the P. chlororaphis strains PCL1606, GP72, O6, and 30-84. Genes distantly related to fitD ( 27 to $28 \%$ identity) are present in the genomes of Q8r1-96, Q2-87, and Pf0-1 but the other genes of the fit locus are not present in these strains.

A comparative analysis of the three sets of genes encoding for antifungal compounds in the genome of $P$. chlororaphis PCL1606 (HPR, HCN, and PRN) demonstrated that the gene size and the synteny of the three gene clusters are very similar in the analyzed Pseudomonas strains.

The gene cluster for $\mathrm{HCN}$ production was detected in all the strains, except in $P$. fluorescens SBW25. The three genes involved in HCN biosynthesis displayed high similarity (more than $74 \%$ ) at the amino acid level and high synteny in the nine compared Pseudomonas strains (Supplementary Fig. S2).

The other two antifungal compounds present in P. chlororaphis PCL1606 (PRN and HPR) are exclusive to the P. chlororaphis strains, except PRN, which is also present in $P$. protegens Pf-5. Genes encoding for both compounds displayed high similarity at the amino acid level among the $P$. chlororaphis sequences when compared with that of PCL1606 (91 to 96\% for PRN [Supplementary Fig. S3] and 82 to $91 \%$ for HPR [Supplementary Fig. S4]). These percentages of homology suggest high similarity but a level of diversity among of the genes present in $P$. chlororaphis PCL1606 related to the other $P$. chlororaphis strains.

An important aspect in this study is that these three analyzed cluster genes are present in the Pseudomonas strains that belong to subclade 1 and all of these genes had high similarity at the amino acid level, which indicates the similar properties between these strains.

\section{Role of antifungal antibiotic production in the biocontrol ability of $P$. chlororaphis PCL1606.}

An analysis of the secondary metabolite encoding genes present in the genome of $P$. chlororaphis PCL1606 (Table 4) revealed the presence of biosynthetic genes that could be involved in the production of such antifungal compounds. These antifungal metabolites have been previously described as involved in the biocontrol ability in Pseudomonas spp., such as HCN (Michelsen and Stougaard 2012; Ramette et al. 2011), PRN (Burkhead et al. 1994; Hill et al. 1994) and HPR (Calderón

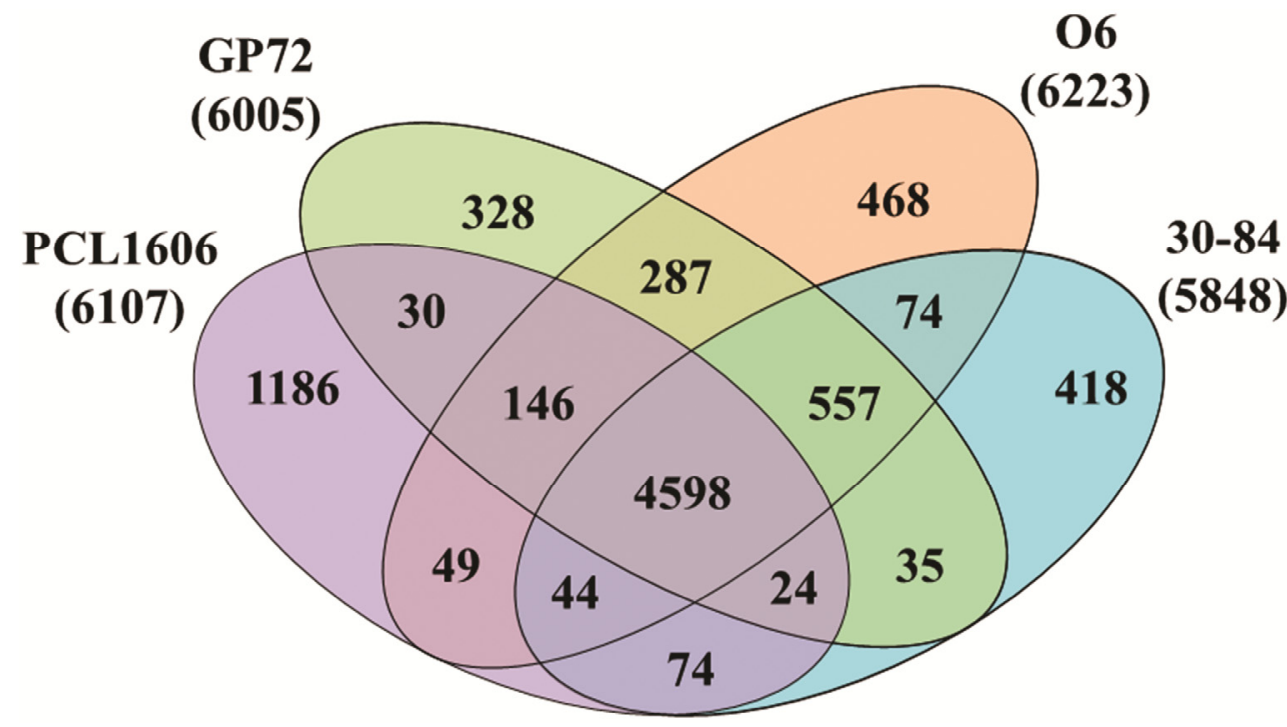

Fig. 3. Genomic diversity of Pseudomonas chlororaphis strains. Each strain is represented by an oval. The number of orthologous protein-coding genes shared by all strains (i. e., the core genome) is in the center. Overlapping regions show the number of coding sequences (CDS) conserved only within the specified genomes. Numbers in the nonoverlapping portions of each oval show the number of CDS unique to each strain. The total number of protein coding genes within each genome is listed below the strain name. 
et al. 2013; Cazorla et al. 2006). The production of HPR and HCN was previously reported in P. chlororaphis PCL1606 (Cazorla et al. 2006). Therefore, this is the first report of PRN production in $P$. chlororaphis PCL1606. To confirm PRN production, after testing different media and conditions, organic extractions after 5 days of growth in King's B medium (KB) at $25^{\circ} \mathrm{C}$ revealed low PRN production that was not always consistent (Supplementary Fig. S5). Therefore, the functionality of the PRN genes was confirmed in this strain (Table 5); however, the production was much reduced and could only be detected under very specific conditions (5 days of growth on $\mathrm{KB}$ at $25^{\circ} \mathrm{C}$ ).

To determine the potential role of these antifungal antibiotics in the biocontrol ability of $P$. chlororaphis PCL1606, sitedirected insertional mutants were constructed in the biosynthetic genes of each antibiotic (HPR, HCN, and PRN). Mutagenesis has been previously used to demonstrate that antibiotics produced by Pseudomonas spp. play important roles in the biological control of plant disease (Anjaiah et al. 1998; Calderón et al. 2013; Chin-A-Woeng et al. 1998; Cronin et al. 1997; Hokeberg et al. 1998; Keel et al. 1990; Thomashow and Weller 1988; Vincent et al. 1991). Single, double, and triple insertional mutants within the different antifungal antibiotic genes were constructed $(\triangle \mathrm{HPR}, \Delta \mathrm{HCN}, \triangle \mathrm{PRN}, \Delta \mathrm{HPR}-\mathrm{HCN}$, $\triangle$ HPR-PRN, $\triangle$ HCN-PRN, and $\triangle$ HPR-HCN-PRN) and phenotypic characterization of each derivative mutant was performed. The derivative strains did not have any antibiotic production, depending on the disrupted gene (Table 5). The phenotypic characterization of these derivative mutants does not reveal altered growth on rich (KB) or minimal medium (M9) (data not shown).

The insertional mutants were then tested for their antagonistic activity against $R$. necatrix $\mathrm{CH} 53$ and $F$. oxysporum f. sp. radicis-lycopersici ZUM2407 using an agar plate assay. The antagonistic activity of the derivative mutants that had a disrupted biosynthetic gene, $\operatorname{dar} B$ (single, double, and the triple mutant), was markedly reduced. $\operatorname{dar} B$ is a key gene involved in the biosynthesis of HPR in PCL1606 (Calderon et al. 2013). Disruption of this gene resulted in failure of HPR production and antagonism against fungi. Derivative mutants with biosynthetic HCN and PRN genes (single and double mutants) retained their antifungal activity and exhibited a phenotype consistent with the wild-type PCL1606 (Table 5). The degree of antagonism displayed by the mutants was clearly correlated with HPR production, based on the lack of fungal antagonism in the derivatives, which confirms the crucial role of HPR production in biological control (Calderón et al. 2013, 2014b; Cazorla et al. 2006).

The effectiveness of producing antibiotics in biocontrol and, more generally, in microbial interactions has often been questioned due to the indirect nature of the supporting evidence and the perceived constraints to antibiotic production in rhizosphere environments (Raaijmakers et al. 2002). However, antibiotic compounds produced by root-colonizing fluorescent pseudomonads may play a significant role in suppressing soilborne diseases in crops (Dowling and O'Gara 1994).

Biocontrol assays against avocado white root rot and tomato foot and root rot were conducted as previously described (Cazorla et al. 2006). When no bacteria were applied to the avocado roots, more than $70 \%$ of the plants infected with $R$. necatrix showed disease (Fig. 4). However, under our experimental conditions, root inoculation with the wild-type $P$. chlororaphis PCL1606 strain reduced the disease index (DI) to $42.6 \%$. The derivative mutants $\triangle \mathrm{HCN}, \triangle \mathrm{PRN}$, and $\triangle \mathrm{HCN}-\mathrm{PRN}$ showed disease indices of $42.6,40.7$, and $46.3 \%$, respectively, which were not significantly different from the control PCL1606 strain. In contrast, all the derivative mutants where the biosynthetic gene for the production of HPR was interrupted $(\triangle \mathrm{HPR}, \triangle \mathrm{HPR}-\mathrm{HCN}$,

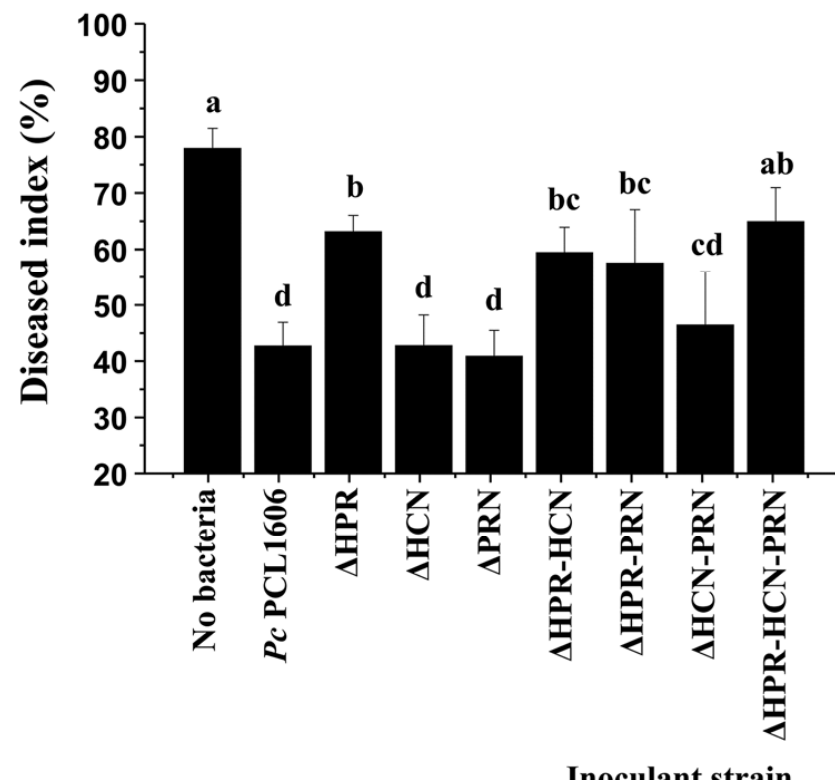

Inoculant strain

Fig. 4. Biocontrol of Rosellinia necatrix-induced white root rot in avocado plants resulting from Pseudomonas chlororaphis PCL1606 and its derivative mutants on the three different antibiotics produced. Single, double, and triple derivative mutants in 2-hexyl, 5-propyl resorcinol ( $\triangle \mathrm{HPR})$, hydrogen cyanide $(\triangle \mathrm{HCN})$, and pyrrolnitrin $(\triangle \mathrm{PRN})$ were assayed. Roots from commercial 6-month-old avocado plants were inoculated with the derivative strains before being transferred to potting soil that was infected with $R$. necatrix. Plants were scored as sick or healthy 21 days after bacterization. Data were analyzed for significance using an arcsine square root transformation with analysis of variance followed by Fisher's least significant difference test $(P=0.05)$. Values with different letter indications denote a statistically significant difference.

Table 5. Main characteristics of the derivative strains of Pseudomonas chlororaphis PCL1606 used in this study

\begin{tabular}{|c|c|c|c|c|c|}
\hline \multirow[b]{2}{*}{ Strain } & \multicolumn{3}{|c|}{ Antibiotics production ${ }^{a}$} & \multicolumn{2}{|c|}{ Antagonism to ${ }^{b}$} \\
\hline & HPR & $\mathrm{HCN}$ & PRN & Rosellinia necatrix & Fusarium oxysporum \\
\hline P. chlororaphis PCL1606 & + & + & + & + & + \\
\hline$\Delta \mathrm{HPR}$ & - & + & + & - & - \\
\hline$\triangle \mathrm{HCN}$ & + & - & + & + & + \\
\hline$\triangle \mathrm{PRN}$ & + & + & - & + & + \\
\hline$\triangle \mathrm{HPR}-\mathrm{HCN}$ & - & - & + & - & - \\
\hline$\Delta$ HPR-PRN & - & + & - & - & - \\
\hline$\triangle \mathrm{HCN}-\mathrm{PRN}$ & + & - & - & + & + \\
\hline$\Delta$ HPR-HCN-PRN & - & - & - & - & - \\
\hline
\end{tabular}

\footnotetext{
${ }^{\text {a }}$ Production of the antibiotics 2-hexyl, 5 propyl resorcinol (HPR) and pyrrolnitrin (PRN), detected by think-layer chromatography analysis, and the volatile compound hydrogen cyanide $(\mathrm{HCN})$, detected by a colorimetric assay.

${ }^{b}$ Bacterial strains showing a mycelial inhibition zone after 5 days of growth were considered antagonistic.
} 
$\triangle$ HPR-PR, and $\triangle$ HPR-HCN-PRN) were shown to have lost significant biocontrol activity when using the avocado- $R$. necatrix test system, with disease indices of $63,59.3,57.4$, and $64.8 \%$, respectively, which are significantly higher disease indices than the wild-type strain (Fig. 4).

The site-directed mutants were also tested in a tomato-F. oxysporum f. sp. radicis-lycopersici biocontrol system (Fig. 5), which produced results similar to those observed in the avocado- $R$. necatrix test system. When no bacteria were added, $94.4 \%$ of the plants showed typical disease symptoms after 21 days of growth in soil that was infested with $F$. oxysporum spores, whereas the introduction of the wild-type $P$. chlororaphis PCL1606 strain reduced the disease incidence to $43 \%$. The $\triangle \mathrm{HCN}, \triangle \mathrm{PRN}$, and $\triangle \mathrm{HCN}-\mathrm{PRN}$ derivative mutants had disease indices of 55,55 , and $51.3 \%$, respectively, which is not significantly different from the control PCL1606 strain. However, we observed a decrease in the biocontrol activity of these derivative mutants. In contrast, as occurs in avocado- $R$. necatrix system, all the derivative mutants where the biosynthetic gene for the production of HPR was mutated $(\triangle \mathrm{HPR}, \triangle \mathrm{HPR}-\mathrm{HCN}$, $\triangle$ HPR-PR, and $\triangle$ HPR-HCN-PRN) showed no significant biocontrol activity in the avocado- $R$. necatrix test system, with disease indices of $83.8,78.7,74.5$, and $86.5 \%$, respectively, similar to the diseased plants when no bacteria were added and significantly different from the wild-type strain (Fig. 5).

Both biocontrol test systems (avocado- $R$. necatrix and tomato- $F$. oxysporum) confirmed that HPR production is crucial in the biocontrol ability of $P$. chlororaphis strain PCL1606, as was previously demonstrated (Calderón et al. 2013). Thus, a secondary role for $\mathrm{HCN}$ and PRN production can be assigned during the biocontrol interaction under our experimental conditions.

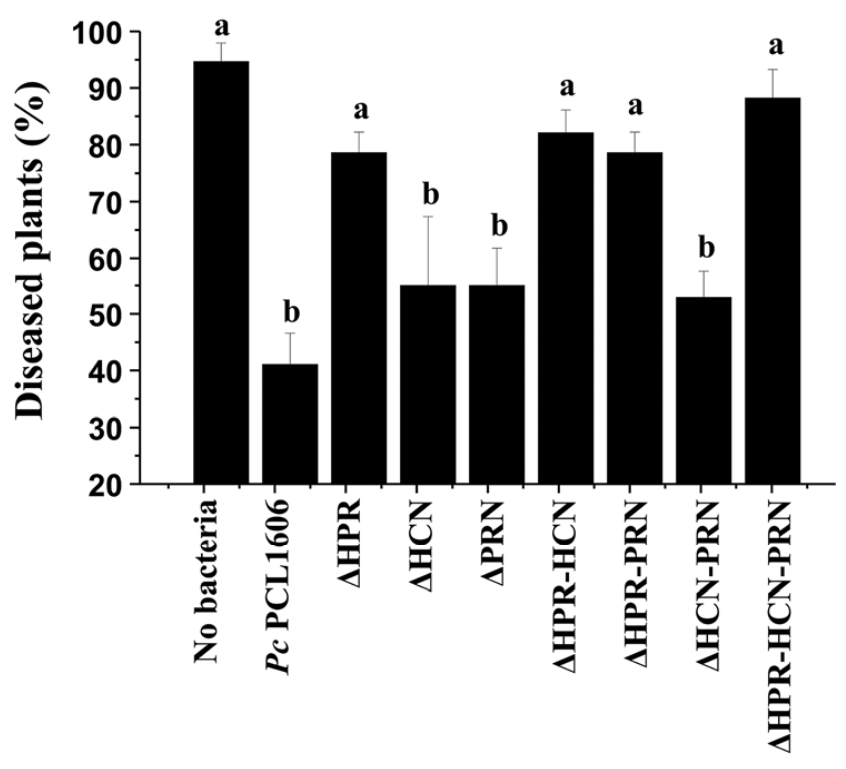

Inoculant strain

Fig. 5. Biocontrol of Fusarium oxysporum f. sp. radicis-lycopersiciinduced tomato foot and root rot resulting from Pseudomonas chlororaphis PCL1606 and its derivative mutants on the three different antibiotics produced. Single, double, and triple derivative mutants in 2-hexyl, 5-propyl resorcinol $(\triangle \mathrm{HPR})$, hydrogen cyanide $(\triangle \mathrm{HCN})$, and pyrrolnitrin $(\triangle \mathrm{PRN})$ were assayed. Tomato seed were coated with bacteria prior to being grown in soil infected with Fusarium spores. Plants were scored as healthy or sick after 21 days of growth. Data were analyzed for significance using an arcsine square root transformation with analysis of variance followed by Fisher's least significant difference test $(P=0.05)$. Values of bars with different letter designations represent a statistically significant difference.
It is important to remark on the dual effect of HPR production in biocontrol, which has a direct effect on the fungal strain and is involved in the efficient colonization of the avocado root (Calderón et al. 2014b).

In conclusion, the genome sequencing of the biocontrol strain $P$. chlororaphis PCL160 provided a phylogenetic study that grouped this strain into the fluorescent group of Pseudomonas, being placed close to the $P$. chlororaphis clade. However, bioinformatics analysis of this genome revealed clear differences with the genome from other representative $P$. chlororaphis strains already sequenced. Some remarkable aspects are the absence of genes involved in phenazine biosynthesis and the presence of genes involved in pyochelin biosynthesis. Moreover, the roles in biocontrol of the antifungal compounds present in PCL1606 have been elucidated, revealing a minor role of HCN and PRN but a major role of HPR when controlling phytopathogenic soilborne fungal pathogens under our experimental conditions.

\section{MATERIALS AND METHODS}

\section{Genome sequencing and annotation.}

Genomic DNA from P. chlororaphis PCL1606 was extracted from bacterial cells growing in an overnight culture in tryptonepeptone-glycerol (TPG) medium at $25^{\circ} \mathrm{C}$ and $150 \mathrm{rpm}$ using the Genomic DNA Purification JETFLEX kit (Genomed GmbH, Löhne, Germany). To verify DNA quality, polymerase chain reaction (PCR) amplifications were performed in a final volume of $25 \mu \mathrm{l}$, which contained $10 \mu \mathrm{M}$ each primer, $2.5 \mathrm{U}$ of GoTaq Flexi DNA polymerase (Promega Corp., Madison, WI U.S.A.), dNTP mixture (250 $\mu \mathrm{M}$ each dNTP), $2 \mathrm{mM} \mathrm{MgCl}_{2}$, $1 \times$ GoTag Flexi buffer, and approximately $50 \mathrm{ng}$ of template DNA. The PCR amplification conditions consisted of an initial denaturation for $2 \mathrm{~min}$ at $94^{\circ} \mathrm{C}$; followed by 30 cycles of denaturation at $94^{\circ} \mathrm{C}$ for $1 \mathrm{~min}$, annealing at $61^{\circ} \mathrm{C}$ for $1 \mathrm{~min}$, and extension at $72^{\circ} \mathrm{C}$ for $1 \mathrm{~min}$; and then a final extension at $72^{\circ} \mathrm{C}$ for $10 \mathrm{~min}$. The PCR products were analyzed for size and quantity by electrophoresis on $1 \%$ agarose gels in Tris-acetateEDTA buffer (40 mM Tris-HCl and $1 \mathrm{mM}$ EDTA, pH 8). Ethidium bromide was used at a concentration of $1 \mu \mathrm{l} / \mathrm{ml}$ to visualize the DNA bands.

The genome of $P$. chlororaphis PCL1606 was sequenced at the BGI company (BGI Tech Solutions Co., Ltd., China) using the Illumina Hiseq 2000 sequencing platform and was assembled using SOAP denovo software ( $\mathrm{Li}$ et al. 2008, 2010). To help during the assembly process, the sequence of $P$. chlororaphis O6, which has the higher chromosome size, was used.

The genome of $P$. chlororaphis PCL1606 was automatically annotated using the services of ChunLab Inc. (Seoul, Korea). Manual curation and the comparative analysis was performed using the CLgenomics v.1.1.2 software.

\section{Genome comparisons.}

The genome sequence of $P$. chlororaphis PCL1606 was aligned against the sequences of other Pseudomonas spp. genomes obtained from the National Center for Biotechnology Information's Entrez database and the EzGenome database. The accession numbers for the nine Pseudomonas spp. genomes used in the comparative analysis with $P$. chlororaphis PCL1606 were AHAY00000000 (P. chlororaphis GP72), AHOT00000000 (P. chlororaphis O6), AHHJ00000000 (P. chlororaphis subsp. aureofaciens 30-84), CP000076 (P. protegens Pf-5), CP000094 (P. fluorescens Pf0-1), AHPO00000000 (P. brassicacearum Q8r1-96), AGBM00000000 (P. fluorescens Q2-87), AM181176 (P. fluorescens SBW25), and CP003150 (P. fluorescens F113). These Pseudomonas strains were selected for further comparison purposes based on their characterized and distinctive bio- 
logical control properties and their isolation from different habitats (bulk, rhizospheric soil, or aerial plant surfaces) Table 1).

Amino acid alignments to detect secondary metabolites were performed using the CLC Main Workbench (Aarhus). The four chlororaphis genomes (PCL1606, GP72, O6, and 3084) were compared using a Venn diagram analysis software (VENNY, Computational Genomics). Core genes among compared strains were obtained using the "comparative genomics" tool of CLgenomics software.

\section{Phylogenetic studies.}

A phylogenetic analysis of $P$. chlororaphis PCL1606, including other strains belonging to the genus Pseudomonas, was performed using a multilocus sequence analysis of the concatenated alignments of eight highly conserved housekeeping genes: rpoB, rpoD, gyrB, recA, acsA, aroE, mutL, and guaA. Multiple alignments were performed using ClustalW (Larkin et al. 2007) and a phylogenetic tree was constructed using the neighbor-joining method (Saitou and Nei 1987). The percentage of replicate trees in which the associated taxa were clustered in the bootstrap test $(1,000$ replicates) is shown next to the branches (Felsenstein 1985). All positions containing gaps and missing data were eliminated from the dataset (complete deletion option). The concatenated sequences of the housekeeping genes yielded an alignment with approximately 15,000 nucleotides that could be compared among all selected strains. The phylogenetic analyzes were conducted using MEGA 5 (Tamura et al. 2011).

\section{Phenotypic characterization of the antifungal antibiotics produced by $P$. chlororaphis PCL1606.}

Microorganism cultures and conditions. The bacterial strains used for the phenotypic characterization of the antibiotics are listed in Table 6. TPG medium (triptone, peptone, and glycerol, each component at $10 \mathrm{~g} / \mathrm{liter}$ ) was routinely used to culture Pseudomonas strains at $25^{\circ} \mathrm{C}$. Agar-agar (Difco Laboratories, Detroit) was added to a final concentration of $1.5 \%$ to produce solid media. Luria Bertani (LB) (Bertani 1951) medium was used to grow Escherichia coli strains at $37^{\circ} \mathrm{C}$. The bacterial strains were stored at $-80^{\circ} \mathrm{C}$ in $\mathrm{LB}$ with $10 \%$ dimethyl sulfoxide. When necessary, the media were supplemented with kanamycin $(50 \mu \mathrm{g} / \mathrm{ml})$, gentamicin $(30 \mu \mathrm{g} / \mathrm{ml})$, or spectinomycin $(50 \mu \mathrm{g} / \mathrm{ml})$.

The fungal strains used in this study (Table 6) were grown at $25^{\circ} \mathrm{C}$ on potato dextrose agar (PDA) (Difco Laboratories) or TPG plates. $R$. necatrix was stored at $4^{\circ} \mathrm{C}$ as previously described (Gutierrez-Barranquero et al. 2012) and $F$. oxysporum spores were stored in $10 \%$ glycerol at $-80^{\circ} \mathrm{C}$.

The plasmids used in this study for cloning purposes are also listed in Table 6.

Construction of $\mathrm{P}$. chlororaphis PCL1606 insertional mutants. PCR, cloning, and plasmid purification were performed following standard procedures (Sambrook and Russell 2001). The selected biosynthetic genes of HPR, PRN, and HCN (darB, prnC, and $h c n B$, respectively) were inactivated by insertional mutagenesis as previously described (Calderón et al. 2013), and the resulting antibiotic production was measured on TPG and KB (King et al. 1954). To accomplish this inactivation, vectors were constructed via insertion to disrupt the various antibiotic biosynthesis genes using single-crossover homologous recombination. To construct the integrative plasmids, DNA fragments of 379 , 743 , and $596 \mathrm{bp}$ from inside the open reading frame of the darB, $h c n B$, and prnC biosynthetic genes, respectively, were obtained using specific PCR primers and $P$. chlororaphis PCL1606 as template. The amplified DNA fragments were then cloned into the pCR2.1-TOPO, pJQ200SK, and pSW25T vectors (Table 6). These integrative plasmids were then transformed into wild-type P. chlororaphis PCL1606 using standard electroporation (Choi et al. 2006). Five colonies from each independent transformation assay were randomly selected and the correct insertion and orientation of the plasmid within the target gene were confirmed by PCR. The resulting derivative mutants were named $\triangle \mathrm{HPR}$, $\triangle \mathrm{HCN}$, and $\triangle \mathrm{PRN}$ for the simple insertional mutants; $\triangle \mathrm{HPR}$ HCN, $\triangle$ HPR-PRN, and $\triangle \mathrm{HCN}-\mathrm{PRN}$ for the double insertional mutants; and $\triangle \mathrm{HPR}-\mathrm{HCN}-\mathrm{PRN}$ for the triple insertional mutant. The insertional mutants were selected in the presence of kanamycin, gentamycin, or spectinomycin, depending on the vector. Additionally, the mutants were analyzed for appropriate insertion using PCR and then sequencing to confirm gene disruption. Growth on M9 minimal medium and TPG compared with the wild-type strain confirmed that these mutants did not have altered growth.

Table 6. Bacterial and fungal strains and plasmids used in this study

\begin{tabular}{|c|c|c|}
\hline Strain & Relevant characteristics $^{\text {a }}$ & Reference or source $^{b}$ \\
\hline \multicolumn{3}{|l|}{ Bacterial strain } \\
\hline \multicolumn{3}{|l|}{ Pseudomonas chlororaphis } \\
\hline PCL1606 & Wild-type, isolated from Spanish avocado rhizosphere. & Cazorla et al. 2006 \\
\hline$\Delta \mathrm{HPR}$ & PCL1606 derivative insertional mutant in $\operatorname{darB}$ gene, $\mathrm{Km}^{\mathrm{r}}$ & Calderón et al. 2013 \\
\hline$\triangle \mathrm{HCN}$ & PCL1606 derivative insertional mutant in $h c n B$ gene, $\mathrm{Km}^{\mathrm{r}}$ & This study \\
\hline$\triangle \mathrm{PRN}$ & PCL1606 derivative insertional mutant in $\mathrm{prnC}$ gene, $\mathrm{Km}^{\mathrm{r}}$ & This study \\
\hline$\triangle \mathrm{HPR}-\mathrm{HCN}$ & PCL1606 derivative insertional mutant in $\operatorname{dar} B$ and $h c n B$ genes, $\mathrm{Km}^{\mathrm{r}}, \mathrm{Gm}^{\mathrm{r}}$ & This study \\
\hline$\Delta$ HPR-PRN & PCL1606 derivative insertional mutant in $\operatorname{dar} B$ and $p r n C$ genes, $\mathrm{Km}^{\mathrm{r}}, \mathrm{Gm}^{\mathrm{r}}$ & This study \\
\hline$\Delta \mathrm{HCN}-\mathrm{PRN}$ & PCL1606 derivative insertional mutant in $h c n B$ and prnC genes, $\mathrm{Km}^{\mathrm{r}}, \mathrm{Gm}^{\mathrm{r}}$ & This study \\
\hline$\Delta$ HPR-HCN-PRN & PCL1606 derivative insertional mutant in $\operatorname{dar} B, h c n B$, and $\operatorname{prn} C$ genes, $\mathrm{Km}^{\mathrm{r}}, \mathrm{Gm}^{\mathrm{r}}, \mathrm{Spe}^{\mathrm{r}}$ & This study \\
\hline \multicolumn{3}{|l|}{ Escherichia coli } \\
\hline DH5 $\alpha$ & General-purpose host strain & $\begin{array}{l}\text { Boyer and } \\
\text { Roulland-Dussoiz } 1969\end{array}$ \\
\hline \multicolumn{3}{|l|}{ Fungi } \\
\hline Rosellinia necatrix CH53 & Wild-type, isolated from avocado trees with symptoms of white root rot; high virulence & $\begin{array}{c}\text { López-Herrera and } \\
\text { Zea-Bonilla } 2007\end{array}$ \\
\hline $\begin{array}{l}\text { Fusarium oxysporum f. sp. } \\
\text { radicis-lycopersici ZUM2407 }\end{array}$ & Causes crown and foot rot of tomato & IPO-DLO \\
\hline \multicolumn{3}{|l|}{ Plasmids } \\
\hline pCR2.1-TOPO & TA cloning vector for polymerase chain reaction products, $\mathrm{Amp}^{\mathrm{r}}, \mathrm{Km}^{\mathrm{r}}$. & Invitrogen \\
\hline pJQ200SK & Suicide vector, P15A oriV sacB mob, $\mathrm{Gm}^{\mathrm{r}}$ & Quandt and Hynes 1993 \\
\hline pSW25T & $\mathrm{pSW} 25::$ oriT $_{\mathrm{RP} 4} ;$ oriV $_{\mathrm{R} 6 \mathrm{~K} \gamma}, \mathrm{Spe}^{\mathrm{r}}$ & Demarre et al. 2005 \\
\hline
\end{tabular}

\footnotetext{
${ }^{\mathrm{a}} \mathrm{Km}^{\mathrm{r}}, \mathrm{Gm}^{\mathrm{r}}, \mathrm{Spe}^{\mathrm{r}}$, and $\mathrm{Amp}^{\mathrm{r}}=$ resistant to kanamycin, gentamycin, spectinomycin, and ampicillin, respectively.
}

${ }^{\mathrm{b}}$ IPO-DLO = Institute for Plant Protection-Agriculture Research Department, Wageningen, The Netherlands. 
Antagonism. The antagonistic activity of the wild-type and derivative strains was tested using the dual-plate test, as previously described (Cazorla et al. 2006; Geels and Schippers 1983). The initial screening for in vitro antifungal activity against the phytopathogenic fungi $R$. necatrix $\mathrm{CH} 53$ and $F$. oxysporum $\mathrm{f}$. sp. radicis-lycopersici ZUM2407 (Table 6) was performed on TPG and PDA plates as follows. A 0.6-cm-diameter mycelium disk from a 2- to 5-day-old fungal culture was placed in the center of a petri dish and the bacterial strains were inoculated at a distance of approximately $3 \mathrm{~cm}$ from the fungus. Bacterial strains that inhibited mycelial growth after 5 days at $25^{\circ} \mathrm{C}$, as judged by a growth inhibition zone, were considered antagonistic.

Antifungal extraction. The strains used in this study were tested for the production of HCN and the antifungal antibiotics HPR and PRN, as previously described (Cazorla et al. 2006). $\mathrm{HCN}$ detection was performed following the paper indicator procedure described by Castric (1975). To detect HPR and PRN, cell-free supernatants from 5-day-old liquid KB or TPG cultures of the corresponding strains were extracted with chloroform/methanol $(2: 1, \mathrm{vol} / \mathrm{vol})$. The extracted material was fractionated in toluene via thin-layer chromatography (TLC) using silica RP-18F 254 S TLC plates (Merck AG, Darmstadt, Germany). After drying, spots were detected on the chromatogram under UV light at $254 \mathrm{~nm}$ and $R f$ values were calculated. Antibiotic production was also determined by spraying these TLC plates with diazotized sulfanilic acid and watching for a characteristic color change (Whistler et al. 2000). Spots with an $R f$ value of approximately 0.9 that were brown to dark green in color were considered positive for HPR. Spots with an $R f$ value of approximately 0.8 that were maroon in color indicated the presence of PRN. The strain P. chlororaphis PCL1606 were used as the reference for antibiotic production.

Biocontrol assays against avocado white root rot. Biocontrol assays against avocado white root rot were performed using the avocado- $R$. necatrix system, as previously described (Cazorla et al. 2006). Six-month-old commercial avocado plants were obtained from Brokaw nurseries (Brokaw España, S.L., Vélez-Málaga, Spain). The roots from the avocado plants were disinfected by immersion in $0.1 \% \mathrm{NaOCl}$ for $20 \mathrm{~min}$ and then washed and bacterized following the method previously described (Cazorla et al. 2006), with slight modifications. The roots of the avocado plants were immersed in a suspension of the bacterial isolate $\left(10^{9} \mathrm{CFU} / \mathrm{ml}\right)$ or in sterile tap water for 20 min. Any excess bacterial suspension was allowed to drip off, after which the seedlings were placed into pots containing $30 \mathrm{~g}$ of wet potting soil (Jongkind Grond B.V., Aalsmeer, The Netherlands) and infected with $R$. necatrix using inoculated wheat grains (four infected grains per pot) as described previously (Freeman et al. 1986). Five sets of 10 avocado seedlings each were tested per treatment. The seedlings were grown in a chamber at $24^{\circ} \mathrm{C}$ and $70 \%$ relative humidity with $16 \mathrm{~h}$ of daylight and were watered twice per week.

Because it was difficult to monitor the symptoms on the avocado roots due to the overgrowth of $R$. necatrix, aerial symptoms were recorded on a scale of 0 to 3 and a normalized DI was calculated using a previously described formula (Cazorla et al. 2006). The DI was determined approximately 21 days after bacterization.

Biocontrol assays against tomato root rot. Biocontrol trials in the tomato-F. oxysporum f. sp. radicis-lycopersici system were conducted as previously described (Cazorla et al. 2006; Chin-A-Woeng et al. 1998). One-third of a 7-day-old PDA plate culture of the strain $F$. oxysporum $\mathrm{f}$. sp. radicis-lycopersici ZUM2407 was homogenized and inoculated in an Erlenmeyer flask containing $200 \mathrm{ml}$ of potato-dextrose broth. After 3 days of growth at $28^{\circ} \mathrm{C}$ under aeration $(110 \mathrm{rev} / \mathrm{min})$, the fungal material was placed on top of sterile glass wool and the filtrate was adjusted to $5 \times 10^{5}$ spores $/ \mathrm{ml}$. For soil inoculation, spore suspensions were mixed thoroughly with potting soil to a final concentration of $3 \times 10^{6}$ spores $/ \mathrm{kg}$.

Tomato seed (Solanum lycopersicum L. 'Moneymaker') were coated with bacteria by dipping the seed in a mixture of $1 \%$ (wt/vol) methylcellulose (Sigma-Aldrich, St. Louis) and $10^{9} \mathrm{CFU} / \mathrm{ml}$ bacteria in phosphate-buffered saline buffer. Coated seed were dried in a sterile stream of air. One seed was sown in each pot that contained $25 \mathrm{~g}$ of soil approximately 1.5 $\mathrm{cm}$ deep. Ten sets of 10 plants each were included in each treatment. The seedlings were grown in a greenhouse at $24^{\circ} \mathrm{C}$ with $70 \%$ relative humidity and $16 \mathrm{~h}$ of daylight and were watered from the bottom. Diseased plants were counted only after a considerable fraction of the untreated control plants (above 60\%) showed symptoms, which usually occurred 18 days after sowing. The plants were removed from the soil and washed and the plant roots were examined for tomato crown and root rot symptoms, which were detected by the presence of root browning and lesion formation. Roots without any disease symptoms were designated as healthy.

Statistical methods. The data were statistically analyzed using an analysis of variance (Sokal and Rohlf 1986) followed by Fisher's least significant difference test $(P=0.05)$ using SPSS 12 software (SPSS Inc., Chicago). All experiments were performed at least three times.

\section{ACKNOWLEDGMENTS}

This research was supported by the Spanish Plan Nacional I + D + I Grant AGL11-30354-C02-01 and CICE-Junta de Andalucía, Proyecto de Excelencia P10-AGR-5797, both cofinanced by the European Union (FEDER). C. E. Calderon was supported by a grant from FPI, MICINN, Spain.

\section{LITERATURE CITED}

Anjaiah, V., Koedam, N., Nowak-Thompson, B., Loper, J. E., Hofte, M., Tambong, J. T., and Cornelis, P. 1998. Involvement of phenazines and anthranilate in the antagonism of Pseudomonas aeruginosa PNA1 and Tn5 derivatives toward Fusarium spp. and Pythium spp. Mol. PlantMicrobe Interact. 11:847-854.

Arshad, M., and Frankenberger, W. T. J. 1998. Plant growth-regulating substances in the rhizosphere: Microbial production and functions. Adv. Agron. 62:45-151.

Bakker, P. A. H. M., Pieterse, C. M. J., and van Loon, L. C. 2007. Induced systemic resistance by fluorescent Pseudomonas spp. Phytopathology 97:239-243.

Baltrus, D. A., Nishimura, M. T., Romanchuk, A., Chang, J. H., Mukhtar, M. S., Cherkis, K., Roach, J., Grant, S. R., Jones, C. D., and Dangl, J. L. 2011. Dynamic evolution of pathogenicity revealed by sequencing and comparative genomics of 19 Pseudomonas syringae isolates. PLoS Pathol. 7:e1002132.

Bender, C. L., Alarcón-Chaidez, F., and Gross, D. C. 1999. Pseudomonas syringae phytotoxins: Mode of action, regulation, and biosynthesis by peptide and polyketide synthases. Microbiol. Mol. Biol. Rev. 63:266292.

Bertani, G. 1951. A method for detection of mutations using streptomycin dependence in Escherichia coli. Genetics 36:598-611.

Berti, A. D., and Thomas, M. G. 2009. Analysis of achromobactin biosynthesis by Pseudomonas syringae pv. syringae B728a. J. Bacteriol 191:4594-4604.

Boyer, H. W., and Roulland-Dussoix, D. 1969. A complementation analysis of the restriction and modification of DNA in Escherichia coli. J. Mol. Biol. 41:459-472.

Calderón, C. E., Pérez-García, A., de Vicente, A., and Cazorla, F. M. 2013. The dar genes of Pseudomonas chlororaphis PCL1606 are crucial for biocontrol activity via production of the antifungal compound 2-hexyl, 5-propyl resorcinol. Mol. Plant-Microbe Interact. 26:554-565.

Calderón, C. E., Carrión, V. J., de Vicente, A., and Cazorla, F. M. 2014. $d a r R$ and $\operatorname{dar} S$ are regulatory genes that modulate 2-hexyl, 5-propyl resorcinol transcription in Pseudomonas chlororaphis PCL1606. Microbiology 160:2670-2680. 
Calderón, C. E., de Vicente, A., and Cazorla, F. M. 2014. Role of 2-hexyl, 5-propyl resorcinol production by Pseudomonas chlororaphis PCL1606 in the multitrophic interactions in the avocado rhizosphere during the biocontrol process. FEMS (Fed. Eur. Microbiol. Soc.) Microbiol. Ecol. 89:20-31.

Castric, P. A. 1975. Hydrogen cyanide, a secondary metabolite of Pseudomonas aeruginosa. Can. J. Microbiol. 21:613-618.

Cazorla, F. M., Duckett, S., Bergström, E., Noreen, S., Odijk, R, Lugtenberg, B. J. J., Thomas-Oates, J., and Bloemberg, G. V. 2006. Biocontrol of avocado Dematophora root rot by antagonistic Pseudomonas fluorescens PCL1606 correlates with the production of 2-hexyl, 5-propyl resorcinol. Mol. Plant-Microbe Interact. 19:418-428.

Chin-A-Woeng, T. F. C., Bloemberg, G. V., and Lugtenberg, B. J. J. 1998 Biocontrol by phenazine-1-carboxamide-producing Pseudomonas chlororaphis PCL1391 of tomato root rot caused by Fusarium oxysporum $\mathrm{f}$. sp. radicis-lycopersici. Mol. Plant-Microbe Interact. 11:1069-1077.

Choi, K.-H., Kumar, A., and Scheweizer, H. P. 2006. A 10-min method for preparation of highly electrocompetent Pseudomonas aeruginosa cells: Application for DNA fragment transfer between chromosomes and plasmid transformation. J. Microbiol. Methods 64:391-397.

Collins, F. S., Green, E. D., Guttmacher, A. E., and Guyer, M. S. 2003. A vision for the future of genomics research. Nature 422:835-847.

Cornelis, P., Matthijs, S., and Van Oeffelen, L. 2009. Iron uptake regulation in Pseudomonas aeruginosa. BioMetals 22:15-22.

Cronin, D., Möenne-Loccoz, Y., Fenton, A., Dunne, C., Dowling, D. N. and O'Gara, F. 1997. Role of 2,4-diacetylphloroglucinol in the interactions of the biocontrol pseudomonad strain F113 with the potato cyst nematode Globodera rostochiensis. Appl. Environ. Microbiol. 63:13571361

Daborn, P. J., Waterfield, N., Silva, C. P., Au, C. P., Sharma, S., and Ffrench-Constant R. H. 2002. A single Photorhabdus gene, makes caterpillars floppy (mcf), allows Escherichia coli to persist within and kill insects. Proc. Natl. Acad. Sci. U.S.A. 99:10742-10747.

De Bruijn, I., de Kock, M. J. D., Yang, M., de Waard, P., van Beek, T. A., and Raaijmakers, J. M. 2007. Genome-based discovery, structure prediction and functional analysis of cyclic lipopeptide antibiotics in Pseudomonas species. Mol. Microbiol. 63:417-428.

Demarre, G., Guérout, A. M., Matsumoto-Mashimo, C., Rowe-Magnus, D. A., Marlière, P., and Mazel, D. 2005. A new family of mobilizable suicide plasmids based on broad host range R388 plasmid (IncW) and RP4 plasmid (IncPalpha) conjugative machineries and their cognate Escherichia coli host strains. Res. Microbiol. 156:245-255

Dowling, D. N., and O'Gara, F. 1994. Metabolites of pseudomonas involved in the biocontrol of plant disease. Trends Biotechnol. 12:133140

Felsenstein, J. 1985. Confidence limits on phylogenies: An approach using the bootstrap. Evolution 39:783-791.

Freeman, S., Sztejnberg, A., and Chet, I. 1986. Evaluation of Trichoderma as a biocontrol agent for Rosellinia necatrix. Plant Soil 94:163-170.

Geels, F. P., and Schippers, G. 1983. Selection of antagonistic fluorescent Pseudomonas spp., and their root colonization and persistence following treatment of seed potatoes. Phytopathology 108:193-206.

Gross, H., and Loper, J. E. 2009. Genomics of secondary metabolite production by Pseudomonas spp. Nat. Prod. Rep. 26:1408-1446

Gross, H., Stockwell, V. O., Henkels, M. D., Nowak-Thompson, B., Loper, J. E., and Gerwich, W. H. 2007. The genomisotopic approach: A systematic method to isolate products of orphan biosynthetic gene clusters. Chem. Biol. 14:53-63.

Gutierrez-Barranquero, J. A., Pliego, C., Bonilla, N., Calderón, C. E., PérezGarcía, A., de Vicente, A., and Cazorla, F. M. 2012. Sclerotization as a long-term preservation method for Rosellinia necatrix strains. Mycoscience 53:460-465.

Haas, D., and Defago, G. 2005. Biological control of soil-borne pathogens by fluorescent pseudomonads. Nat. Rev. Microbiol. 3:307-319.

Haas, D., and Keel, C. 2003. Regulation of antibiotic production in rootcolonizing Pseudomonas spp. and relevance for biological control of plant disease. Annu. Rev. Phytopathol. 41:117-153.

Han, S. H., Lee, S. J., Moon, J. H., Park, K. H., Yang, K. Y., Cho, B. H., Kim, Y. W., Lee, M. C., Anderson, A. J., and Kim, Y. C. 2006. GacSdependent production of 2R, 3R-butanediol by Pseudomonas chlororaphis $\mathrm{O} 6$ is a major determinant for eliciting systemic resistance against Erwinia carotovora but not against Pseudomonas syringae pv. tabaci in tobacco. Mol. Plant-Microbe Interact. 19:924-930.

Hill, D. S., Stein, J. I., Torkewitz, N. R., Morse, A. M., Howell, C. R., Pachlatko, J. P., Becker, J. O., and Ligon, J. M. 1994. Cloning of genes involved in the synthesis of pyrrolnitrin from Pseudomonas fluorescens and role of pyrrolnitrin synthesis in biological control of plant disease. Appl. Environ. Microbiol. 60:78-85.

Hokeberg, M., Wright, S. A. I., Svensson, M., Lundgren, L. N., and Gerhardson, B. 1998. Mutants of Pseudomonas chlororaphis defective in the production of an antifungal metabolite express reduced biocontrol activity. Abstr. Proc. ICPP98, Edinburgh, Scotland.

Kang, B. R., Yang, K. Y., Cho, B. H., Han, T. H., Kim, I. S., Lee, M. C., Anderson, A. J., and Kim, Y. C. 2006. Production of indole-3-acetic acid in the plant-beneficial strain Pseudomonas chlororaphis O6 is negatively regulated by the global sensor kinase GacS. Curr. Microbiol. 52:473-476.

Keel, C., Wirthner, P., Oberhansli, T., Voisard, C., Burger, Haas, D., and Defago, G. 1990. Pseudomonads as antagonists of plant-pathogens in the rhizosphere: Role of the antibiotic 2,4-diacetylphloroglucinol in the suppression of black root-rot of tobacco. Symbiosis 9:327-341.

Kimbrel, J., Givan, S. A., Halgren, A. B., Creason, A. L., Mills, D. I., Banowetz, G. M., Armstrong, D. J., and Chang, J. H. 2010. An improved, high-quality draft genome sequence of the germination-arrest factor-producing Pseudomonas fluorescens WH6. BMC Genomics 11:522

King, E. O., Ward, M. K., and Raney, D. E. 1954. Two simple media for the demonstration of pyocyanin and fluorescein. J. Lab. Clin. Med. 28:943-946.

Kluepfel, D. A., McInnis, T. M., and Zehr, E. I. 1993. Involvement of rootcolonizing bacteria in peach orchard soils suppressive of the nematode Criconemella xenoplax. Phytopathology 83:1250-1245.

Larkin, M. A., Blackshields, G., Brown, N. P., Chenna, R., McGettigan, P. A., McWilliam, H., Valentin, F., Wallace, I. M., Wilm, A., Lopez, R., Thompson, J. D., Gibson, T. J., and Higgins, D. G. 2007. Clustal W and Clustal X version 2.0. Bioinformatics 23:2947-2948.

Lessie, T. G., and Phibbs, P. V., Jr. 1984. Alternative pathways of carbohydrate utilization in pseudomonads. Annu. Rev. Microbiol. 38:359-388.

Leveau, J. H. J., and Gerards, S. 2008. Discovery of a bacterial gene cluster for catabolism of the plant hormone indole 3-acetic acid. FEMS (Fed. Eur. Microbiol. Soc.) Microbiol. Ecol. 65:238-250.

Li, R., Kristiansen, K. and Wang, J. 2008. SOAP: Short oligonucleotide alignment program. Bioinformatics 24:713-714.

Li, R., Zhu, H., Ruan, J., Qian, W., Fang, X., Shi, Z., Li, S., Shan, G., Kristiansen, K., Li, H., Wang, J., and Wang J. 2010. De novo assembly of human genomes with massively parallel short read sequencing. Genome Res. 20:265-272.

Loper, J. E., and Schroth, M. N. 1986. Influence of bacterial sources of indole-3-acetic acid on root elongation of sugar beet. Phytopathology 76:386-389.

Loper, J. E., Hassan, K. A., Mavrodi, D. V., Davis II, E. W., Lim, C. K., Shaffer, B. T., Elbourne, L. D. H., Stockwell, V. O., Hartney, S. L., Breakwell, K., Henkels, M. D., Tetu, S. G., Rangel, L. I., Kidarse, T. A., Wilson, N. L., van de Mortel, J. E., Song, C., Blumhagen, R., Radune, D., Hostetler, J. B., Brinkac, L. M., Durkin, A. S., Kluepfel, D. A., Wechter, W. P., Anderson, A. J., Kim, Y. C., Pierson, L. S., III, Lindow, S. E., Kobayashi, D. Y., Raaijmakers, J. M., Weller, D. M., Thomashow, L. S., Allen, A. E., and Paulsen, I. T. 2012. Comparative genomics of plant-associated Pseudomonas spp.: Insight into diversity and inheritance of traits involved in multitrophic interactions. PLoS Genet. 8:127.

López-Herrera, C. J., and Zea-Bonilla, T. 2007. Effects of benomyl, carbendazim, fluazinam and thiophanate methyl on white root rot of avocado. Crop Prot. 26:1186-1192.

Lugtenberg, B. J. J., and Kamilova, F. 2009. Plant-growth-promoting rhizobacteria. Annu. Rev. Microbiol. 63:541-556.

Mavrodi, D. V., Blakenfeldt, W., and Thomashow, L. S. 2006. Phenazine compounds in fluorescent Pseudomonas spp.: Biosynthesis and regulation. Annu. Rev. Phytopathol. 44:417-445.

Mazzola, M. 2004. Assessment and management of soil microbial community structure for disease suppression. Annu. Rev. Phytopathol. 42:35-59.

Mazzola, M., Zhao, X., Cohen, M. F., and Raaijmakers, J. M. 2007. Cyclic lipopeptide surfactant production by Pseudomonas fluorescens SS101 is not required for suppression of complex Pythium spp. populations. Phytopathology 97:1348-1355.

Mazzola, M., de Bruijn, I., Cohen, M. F., and Raaijmakers, J. M. 2009. Protozoan-induced regulation of cyclic lipopeptide biosynthesis is an effective predation defense mechanism for Pseudomonas fluorescens. Appl. Environ. Microbiol. 75:6804-6811.

Mendes, R., Kruijt, M., de Bruijn, I., Dekkers, E., van der Voort, M., Schneider, J. H., Piceno, Y. M., DeSantis, T. Z., Andersen, G. L., Bakker, P. A., and Raaijmakers, J. M. 2011. Deciphering the rhizosphere microbiome for disease-suppressive bacteria. Science 332:1097-1100.

Meyer, J. M. 2000. Pyoverdines: Pigments, siderophores and potential taxonomic markers of fluorescent Pseudomonas species. Arch. Microbiol. 174:135-142.

Michelsen, C. F. and Stougaard, P. 2012. Hydrogen cyanide synthesis and antifungal activity of the biocontrol strain Pseudomonas fluorescens In5 from Greenland is highly dependent on growth medium. Can. J. Microbiol. 58:381-390. 
Mulet, M., Lalucat, J., and García-Valdés, E. 2010. DNA sequence-based analysis of the Pseudomonas species. Environ. Microbiol. 12:1513-1530.

Paulsen, I. T., Press, C. M., Ravel, J., Kobayashi, D. Y., Myers, G. S. A., Mavrodi, D. V., Deboy, R. T., Seshadri, R., Ren, Q., Madupu, R., Dodson, R. J., Durkin, A. S., Brinkac, L. M., Daugherty, S. C., Sullivan, S. A., Rosovitz, M. J., Gwinn, M. L., Zhou, L., Schneider, D. J., Cartinhour, S. W., Nelson, W. C., Widman, J., Watkins, K., Tran, K., Khouri, H., Pierson, E. A., Pierson, L. S., III., Thomashow, L. S., and Loper, J. E. 2005. Complete genome sequence of the plant commensal Pseudomonas fluorescens Pf-5. Nat. Biotechnol. 23:873-878.

Pechy-Tarr, M., Bruck, D., Maurhofer, M., Fischer, E., Vogne, C., Henkels, M. D., Donahue, K. M., Grunder, J., Loper, J. E., and Keel, C. 2008. Molecular analysis of a novel gene cluster encoding an insect toxin in plant- associated strains of Pseudomonas fluorescens. Environ. Microbiol. 10:2368-2386.

Pierson, L., and Pierson, E. 2010. Metabolism and function of phenazines in bacteria: Impacts on the behavior of bacteria in the environment and biotechnological processes. Appl. Microbiol. Biotechnol. 86:16591670.

Pliego, C., López-Herrera, C., Ramos, C., and Cazorla, F. M. 2012. Developing tools to unravel the biological secrets of Rosellinia necatrix, and emergent threat to woody crops. Mol. Plant Pathol. 13:226-239.

Quandt, J., and Hynes, M. F. 1993. Versatile suicide vectors which allow direct selection for gene replacement in gram-negative bacteria. Gene 15:15-21.

Raaijmakers, J. M., Vlami, M., and de Souza, J. T. 2002. Antibiotic production by bacterial biocontrol agents. Antonie Leeuwenhoek 81:537547.

Raaijmakers, J. M., de Bruijn, I., and de Kock, M. J. D. 2006. Cyclic lipopeptide production by plant-associated Pseudomonas spp.: Diversity, activity, biosynthesis, and regulation. Mol. Plant-Microbe Interact. 19:699-710.

Raaijmakers, J. M., de Bruijn, I., Nybroe, O., and Ongena, M. 2010. Natural functions of lipopeptides from Bacillus and Pseudomonas: More than surfactants and antibiotics. FEMS (Fed. Eur. Microbiol. Soc.) Microbiol. Rev. 34:1037-1062.

Ramette, A., Frapolli, M., Saux, M. F. L., Gruffaz, C., Meyer, J. M., Défago, G., Sutra, L., and Moënne-Loccoz, Y. 2011. Pseudomonas protegens sp. nov., widespread plant-protecting bacteria producing the biocontrol compounds 2,4-diacetylphloroglucinol and pyoluteorin. Syst. Appl. Microbiol. 34:180-188.

Redondo-Nieto, M., Barret, M., Morrisey, J. P., Germaine, K., MartínezGranero, F., Barahona, E., Navazo, A., Sánchez-Contreras, M., Moynihan, J. A., Giddens, S. R., Coppoolse, E. R., Muriel, C., Stiekema, W. J., Rainey, P. B., Dowling, D., O'Gara, F., Martín, M., and Rivilla, R. 2012. Genome Sequence of the Biocontrol Strain Pseudomonas fluorescens F113. J. Bacteriol. 194:1273.

Rodriguez-Palenzuela, P., Matas, I. M., Murillo, J., Lopez-Solanilla, E., Bardaji, L., Perez-Martinez, I., Rodriguez-Moskera, M. E., Penyalver, R., Lopez, M. M., Quesada, J. M., Biehl, B. S., Perna, N. T., Glasner, J. D., Cabot, E. L., Neeno-Eckwall, E., and Ramos, C. 2010. Annotation and overview of the Pseudomonas savastanoi pv. savastanoi NCPPB 3335 draft genome reveals the virulence gene complement of a tumourinducing pathogen of woody hosts. Environ. Microbiol. 12:1604-1620.

Saitou, N., and Nei, M. 1987. The neighbor-joining method: A new method for reconstructing phylogenetic trees. Mol. Biol. Evol. 4:406-425.

Sambrook, J., and Russell, D. W. 2001. Molecular Cloning: A Laboratory Manual, Third Edition. Cold Spring Harbor Laboratory Press, Cold Spring Harbor, NY, U.S.A.

Selin, C., Habibian, R., Poritsanos, N., Athukorala, S. N., Fernando, D., and de Kievit, T. T. 2010. Phenazines are not essential for Pseudomonas chlororaphis PA23 biocontrol of Sclerotinia sclerotiorum, but do play a role in biofilm formation. FEMS (Fed. Eur. Microbiol. Soc.) Microbiol. Ecol. 71:73-83.

Shen, X., Hu, H., Peng, H., Wang, W., and Zhang, X. 2013. Comparative genomic analysis of four representative plant growth-promoting rhizobacteria in Pseudomonas. BMC Genomics 14:271.

Silby, M. W., and Levy, S. B. 2004. Use of in vitro expression technology to identify genes important in growth and survival of Pseudomonas fluorescens Pf0-1 in soil: Discovery of expressed sequences with novel genetic organization. J. Bacteriol. 186:7411-7419.

Silby, M. W., Cerdeño-Tarraga, A. M., Vernikos, G. S., Giddens, S. R. Jackson, R. W., Preston, G. M., Zhang, X.-.X., Moon, C. D., Gehrig, S. M., Godfrey, S. A. A., Knight, C. G., Malone, J. G., Robinson, Z., Spiers, A. J., Harris, S., Challis, G. L., Yaxley, A. M., Harris, D., Seeger, K., Murphy, L., Rutter, S., Squares, R., Quail, M. A., Saunders, E., Mavromatis, K., Brettin, T. S., Bentley, S. D., Hothersall, J., Stephens, E., Thomas, C. M., Parkhill, J., Levy, S. B., Rainye., P. B., and Thomson, N. R. 2009. Genomic and genetic analyses of diversity and plant interactions of Pseudomonas fluorescens. Genome Biol. 10:R51.

Silby, M. W., Winstanley, C., Godfrey, S. A. C., Levy, S. B., and Jackson, R. W. 2011. Pseudomonas genomes: Diverse and adaptable. FEMS (Fed. Eur. Microbiol. Soc.) Microbiol. Rev. 35:652-680.

Sokal, R. R., and Rohlf, F. J. 1986. Introducción a la bioestadística. Editorial Reverté S.A., Barcelona, Spain.

Spaepen, S., Vanderleyden, J., and Remans, R. 2007. Indole-3-acetic acid in microbial and microorganism-plant signaling. FEMS (Fed. Eur. Microbiol. Soc.) Microbiol. Rev. 31:425-448.

Tamura, K., Peterson, D., Peterson, N., Stecher, G., Nei, M., and Kumar, S. 2011. MEGA5: Molecular evolutionary genetics analysis using maximum likelihood, evolutionary distance, and maximum parsimony methods. Mol. Biol. Evol. 28:2731-2739.

Thomashow, L. S., and Weller, D. M. 1988. Role of phenazine antibiotic from Pseudomonas fluorescens in biological control of Gaeumannomyces graminis var. tritici. J. Bacteriol. 170:3499-3508.

Vincent, M. N., Harrison, L. A., Brackin, J. M., Kovacevich, P. A., Murkerji, P., Weller, D. M., and Pierson, E. A. 1991. Genetic analysis of the antifungal activity of a soilborne Pseudomonas aureofaciens strain. Appl. Environ. Microbiol. 57:2928-2934.

Visca, P., Imperi, F., and Lamont, I. L. 2007. Pyoverdine siderophores: From biogenesis to biosignificance. Trends Microbiol. 15:22-30.

Wandersman, C., and Delepelaire, P. 2004. Bacterial iron sources: From siderophores to hemophores. Annu. Rev. Microbiol. 58:611-647.

Weller, D. M. 1988. Biological control of soilborne plant pathogens in the rhizosphere with bacteria. Annu. Rev. Phytopathol. 26:379-407.

Weller, D. M., Raaijmakers, J. M., Gardener, B. B. M., and Thomashow, L. S. 2002. Microbial populations responsible for specific soil suppressiveness to plant pathogens. Annu. Rev. Phytopathol. 40:309-348.

Weller, D. M., Landa, B. B., Mavrodi, O. V., Schroeder, K. L., De La Fuente, L., Blouin Bakhead, S., Allende Molar, R., Bonsail, R. F. Mavrodi, D. V., and Thomashow, L. S. 2007. Role of 2,4-diacetylphloroglucinol-producing fluorescent Pseudomonas spp. in the defense of plant roots. Plant Biol. 9:4-20.

Whistler, C. A., Stockwell, V. O., and Loper, J. E. 2000. Lon protease influences antibiotic production and UV tolerance of Pseudomonas fluorescens Pf-5. Appl. Environ. Microbiol. 66:2718-2725.

Wilson, M., and Lindow, S. E. 1993. Interactions between the biological control agent Pseudomonas fluorescens A506 and Erwinia amylovora in pear blossoms. Phytopathology 83:117-123.

Wu, X., Monchy, S., Taghavi, S., Zhu, W., Ramos, J., and van der Lelie, D. 2010. Comparative genomics and functional analysis of niche-specific adaptation in Pseudomonas putida. FEMS (Fed. Eur. Microbiol. Soc.) Microbiol. Rev. 35:299-323.

Xiao, Z., and Xu, P. 2007. Acetoin metabolism in bacteria. Crit. Rev. Microbiol. 33:127-140.

Youard, Z. A., Mislin, G. L., Majcherczyk, P. A., Schalk, I. J., and Reimmann, C. 2007. Pseudomonas fluorescens CHA0 produces enantiopyochelin, the optical antipode of the Pseudomonas aeruginosa siderophore pyochelin. J. Biol. Chem. 282:35546-35553.

\section{AUTHOR-RECOMMENDED INTERNET RESOURCES}

CLgenomics program: www.chunlab.com/genomics EzGenome: www.ezbiocloud.net National Center for Biotechnology Information: www.ncbi.nlm.nih.gov SOAP denovo software: soap.genomics.org.cn VENNY: bioinfogp.cnb.csic.es/tools/venny/index.html 